\title{
Comparative economic analysis of crop yield under organic and conventional farming systems in Punjab, Pakistan
}

\author{
Waqas Aslam ${ }^{1}$, Rana Shahzad Noor ${ }^{2}$, Saif Ullah ${ }^{1}$, Hong Chen ${ }^{1 *}$ \\ ${ }^{1}$ College of Economics and Management, Northeast Forestry University, Harbin 150040, China \\ ${ }^{2}$ Department of Agriculture, Biological, Environment and Energy Engineering, College of Engineering, \\ Northeast Agricultural University, Harbin 150030, China.

\begin{abstract}
Agriculture is one of the main sources of economic sustainability across major developed countries in the world. It is in view of these, that this study seeks to investigate the perceived comparative advantage of organic and conventional farming systems in recent times. This study aimed at comparing the inputs and outputs of organic and conventional farming systems in Punjab province in Pakistan. In terms of farm inputs, the study revealed that organic crop farmers experienced higher mean expenses on irrigation and labor force with $12 \%$ and $7 \%$ difference respectively while on fertilizers and pesticides, the conventional farmers' mean expenses were significantly higher. In terms of farm outputs, the study also revealed that the conventional farmers yield was higher than that of the organic farmers by $11 \%$. Irrespective of the findings, it was realized that people preferred to consume organic crops based on the quality of the crops prompted using natural manure unlike the conventional crops where the fertilizers are more of chemicals.
\end{abstract}

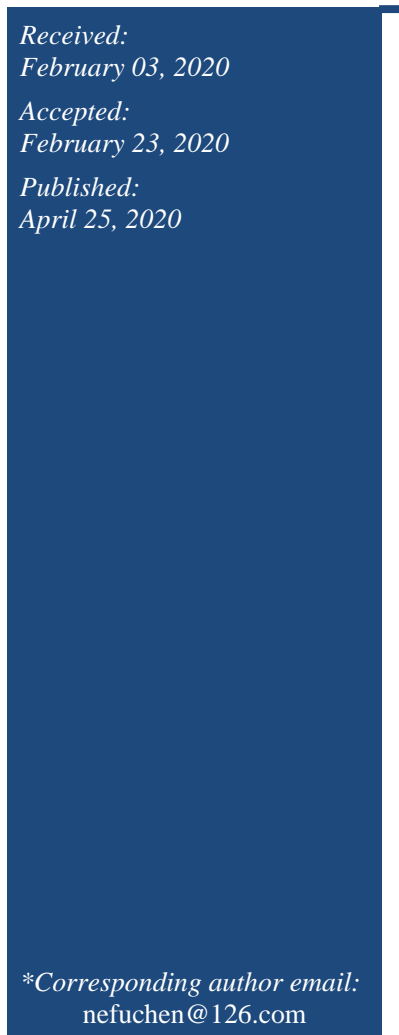

Keywords: Organic, Conventional, Sustainability, Farming system, Agriculture, Yield

\section{How to cite this:}

Aslam W, Noor RS, Ullah S and Chen H, 2020. Comparative economic analysis of crop yield under organic and conventional farming systems in Punjab, Pakistan. Asian J. Agric. Biol. 8(2):113-118. DOI: https://doi.org/10.35495/ajab.2020.02.093

This is an Open Access article distributed under the terms of the Creative Commons Attribution 3.0 License. (https://creativecommons.org/licenses/by/3.0), which permits unrestricted use, distribution, and reproduction in any medium, provided the original work is properly cited.

\section{Introduction}

The technological developments achieved after the Second World War led to innovations in the agricultural sector, as in many sectors. With the rapid population growth, the highest yield was targeted, and the products were increased by up to $100 \%$ with the agricultural technique called "Green Revolution" that was initiated especially in the 1960-1970s. The revolution thus leads to the development of input intensive farming termed conventional farming.
Fertilizer responsive high yielding crop cultivars were developed in this context. These developments lead the extensive use of chemical fertilizers as well as pesticides which improved crop yield but caused contaminations to soil and water environment. These contaminations caused serious health problems in human beings (Taylor et al., 2019). These disadvantages paved the way for research and development of alternative techniques to the conventional farming method. As the other regions of the world is being applied chemicals (fertilizers and 
pesticides, etc.) in agriculture sector of Pakistan. These intensive applications of chemical fertilizer and pesticides/herbicides are not only causing land degradation and climatic damage, but also reducing soil fertility and hence could be a severe threat to food security (Khan et al., 2015).

Organic agriculture is considered as a safer alternative. Recently, the world has turned to organic agriculture only in a healthy and clean environment, in order to live healthy and happy by consuming or using food and non-food products that are healthy and clean without residue. In addition, organic agriculture may contribute to the socio-economic development and ecological sustainability of a country (Husnain et al., 2017). Organic farming system promotes an agricultural practice that emphasizes the use of natural soil fertility and eliminates or minimizes the use of damaging chemical components or products to the most minimal level (Clark, 2009, Stagnari et al., 2013). Organic farming system promotes environmentally friendly agricultural practices (Adhikari, 2009). Consequently, the International Federation of Organic Movements (IFOAM, 2019) describe organic farming system as an agricultural system that promotes soil health, ecosystem sustainability and human wellbeing (Yasin et al., 2014, Bonazzi and Iotti, 2014). Organic farming system is a system that rejects the use of chemical products such as fertilizers, insecticides, pesticides and herbicides on farms (Yasin et al., 2014). Organic agriculture have been observed to have three main dimensions which are economic, social and environmental dimensions towards encouraging and promoting food security (Grogan, 2012).It is in this regards that this study seeks to examine and understand the farming system utilized and adopted in Punjab province of Pakistan. The current study was planned to assess the Comparative analysis of yield and economic sustainability of organic and conventional of wheat.

Agriculture is one of the main sources of socioeconomic enhancement and sustainability across the world (Qiao et al., 2019). Thus, adequate care must be taken in ensuring the best and operational practices are adopted to yield its main aim of diversifying the economy and food security. Agriculture holds a vital position in Pakistan's economy, and it accounts for $24 \%$ of GDP in 2018 . Over $40 \%$ of Pakistan's total area is under cultivation within period of sixty years (FAOSTAT, 2017). In recent times, conventional farming system has been confirmed to provide $98.1 \%$ of the world's agricultural products (Pleadin et al., 2017) .

Organic farming is one of the approaches that can contribute to food and nutritional safety in sustainable agriculture. Environmentally oriented approaches encourage consumers to consume more organic food and producers to produce more organic food. With the advancement in food production techniques, significant increases and variations in the production of foodstuffs have emerged. However, the widespread use of these substances triggered the emergence of various diseases that may also affect cancer, obesity and genetics. Concerns in the minds of consumers have begun to differentiate their food consumption preferences. This differentiation prompted consumers to prefer healthier and higher quality products (Lusk and McCluskey, 2018).

As organic farming system has received increasing interest across the world, so, at the end of 2017 more than 69.8 million hectares were organically cultivated globally which depicts $20 \%$ increase as compared with the previous year as 11.7 million hectare. The observed growth in organic farming system across major developing countries of Asia was prompted by an increasing rate of exporters of organic products to developed countries of Europe and North America (Khan et al., 2015). The practice of organic farming system in Pakistan can be traced back to 1996 when a non-governmental and non-profit organization called Lok Sanjh, organized trainings for local farmers to help improve their knowledge on the use of organic farming system (Husnain et al., 2017).

\section{Material and Methods}

The case study is on wheat farms located in two major districts of Toba Tek Singh and Jhang, in Punjab province, Pakistan. The choice of the districts was mindful of a wide consultation with principal stakeholders of the area. Typically, farmers grow two main crops annually within two seasons named Rabi and kharif. The major crops grown in the area is wheat which is cultivated by $78 \%$ of the farmer during the Rabi season, comprising an area of approximately 8.6 million meters, which take over $40 \%$ of the total cultivated land in the area.

A total of 300 farmers were purposively adopted for this study through a purposive sampling technique. The farmers were understood to practice both conventional and organic farming system across the two areas. A semi-structured questionnaire was 
selected to the farmer to help elicit information for the study. The questionnaire aided the collection of data on the following items; family characteristics, farm structure and management, farmers practice inputs and outputs. Data were analyzed using descriptive and inferential statistical technique and were presented with the aid of tabular form.

\section{Results and Discussion}

The survey investigation revealed that 153 out of the total of 300 farmers were involved in organic farming system while the remaining 147 from the total 300 farmers were involved in conventional farming system (Table 2) in 2019. In the case of the farmer's characteristics in the study area, information on table 1 shows that 156 farmers representing 52\% of the entire farmers under investigation were educated (have passed high school) and 144 farmers representing $48 \%$ of the entire farmers were illiterates (have not or have completed primary education) (Table 2). Further investigation also revealed that among the educated farmers, 95 farmers representing $61 \%$ were involved in Organic farming and 61 farmers representing $39 \%$ were involved in conventional farming while among the 144 illiterate farmers, 86 representing $60 \%$ of the illiterate farmers were involved in conventional farming and 58 farmers representing $40 \%$ of the illiterate farmers were involved in organic farming system. With these, one could deduce that organic farming was practiced by people or farmers with high educational level than those involved in conventional farming. It was also realized that 174 farmers $(58 \%)$ of the entire farming population were involved in other complementary jobs to the farming business while 126 farmers (42\%) were fully involved and relied on the proceeds from their farms. The study further revealed that the reason for most farmers engaging in complementary jobs were due to the quest for more income, low level of agricultural incomes, high risk involved in agricultural business and cyclical production observed in agricultural sector.

In terms of income, organic farmers mean monthly income was PKR 63,000 which is much lower than that earned by conventional farmers (PKR 80,000) as presented in Table 2. The mean monthly income revealed that the earnings from conventional farmers was significantly more than that from organic farmers irrespectively of the number of farmers involved in the two farming systems where it was observed that the organic farmers were slightly more in number than their conventional counterparts.

Table-1: Region wise personal information of farmers across the study area (2019)

\begin{tabular}{|c|c|c|c|c|}
\hline \multirow{2}{*}{ Farming system } & \multicolumn{2}{|c|}{ Toba Tek Singh } & \multicolumn{2}{c|}{ Jhang } \\
\cline { 2 - 5 } & Organic & Conventional & Organic & Conventional \\
\hline $\begin{array}{c}\text { Farmers } \\
\text { Involvement }\end{array}$ & $88(29)^{*}$ & $95(32)$ & $65(22)$ & $52(17)$ \\
\hline Educated farmers & $52(33)$ & $31(20)$ & $43(28)$ & $30(19)$ \\
\hline Illiterate farmers & $37(26)$ & $42(29)$ & $21(15)$ & $44(31)$ \\
\hline Full time farmers & $38(30)$ & $24(19)$ & $44(35)$ & $20(16)$ \\
\hline Part time farmers & $44(25)$ & $46(26)$ & $30(17)$ & $54(31)$ \\
\hline $\begin{array}{c}\text { Mean Monthly } \\
\text { income (PKR) }\end{array}$ & $\begin{array}{c}3750 \\
(19)\end{array}$ & $4210(21)$ & $4620(23)$ & $7690(38)$ \\
\hline $\begin{array}{c}\text { Farmland for } \\
\text { wheat cultivation } \\
\text { (ha) }\end{array}$ & $520(22)$ & $610(26)$ & $640(27)$ & $582(25)$ \\
\hline
\end{tabular}

*, Percentage

Table-2: Characteristics of farmers across the study area (2019)

\begin{tabular}{|l|c|c|c|}
\hline \multicolumn{2}{|c|}{ Items } & Organic & Conventional \\
\hline \multicolumn{2}{|c|}{ Adoption of Farming System } & 51 & 49 \\
\hline \multirow{2}{*}{ Mean Monthly Income } & 56 & 44 \\
\hline \multirow{2}{*}{ Education Level } & Literate & 48 & 52 \\
\cline { 2 - 4 } & Ill-Literate & 52 & 48 \\
\hline
\end{tabular}

\section{Inputs and outputs of organic and conventional farms}

In this section, the study shall examine the inputs and outputs as well as the yield of organic and conventional farms. According to the information on Table 3, there was a comparison between the inputs and outputs on organic and conventional farms across the study area. From Table 3, it was shown that irrigation cost for organic farm is PKR 15,249.77 (PKR 7933.36 and PKR 7316.41) while the conventional farms is PKR 13,564.49 (PKR 7651.24 and PKR 5913.25). This means that the cost of irrigation used on the organic farms is significantly higher than the cost of irrigation applied to the conventional farms by $12 \%$ meaning that more water is used in an organic farming system. This is in line with the findings of (Testa et al., 2014) who stated that organic farming system consume more irrigation water than the conventional farms. In terms of fertilizer expenses, it was realized that the two farming systems used different form of fertilizers, while the organic system used poultry and livestock manure as fertilizer and the conventional farms used the NPK (Nitrogen, Phosphorus and Potassium) was used. 
Waqas Aslam et al.

Table-3: Inputs and outputs (PKR) for organic and conventional wheat farming systems

\begin{tabular}{|c|c|c|c|c|c|c|c|c|}
\hline \multirow{2}{*}{$\begin{array}{c}\text { Cost/ha } \\
(\$)\end{array}$} & \multicolumn{5}{|c|}{ Toba Tek Singh } & \multicolumn{5}{c|}{ Jhang } \\
\cline { 2 - 9 } & Organic & Conventional & M. diff. & T-Stat. & Organic & Conventional & M. diff. & T-Stat. \\
\hline Water & $\begin{array}{c}7933.36 \\
(1186.18)\end{array}$ & $\begin{array}{c}7651.24 \\
(1004.12)\end{array}$ & 596.99 & 0.39 & $\begin{array}{c}7316.41 \\
(998.64)\end{array}$ & $\begin{array}{c}5913.25 \\
(341.63)\end{array}$ & 1462.07 & 1.67 \\
\hline Fertilizer & $\begin{array}{c}10761.11 \\
(1021.02)\end{array}$ & $\begin{array}{c}14036.60 \\
(802.16)\end{array}$ & 3103.12 & 2.02 & $\begin{array}{c}9136.02 \\
(741.92)\end{array}$ & $\begin{array}{c}15941.46 \\
(781.16)\end{array}$ & $5960.70^{*}$ & 5.9 \\
\hline Labor & $\begin{array}{c}13963.41 \\
(1001.01)\end{array}$ & $\begin{array}{c}12681.25 \\
(911.63)\end{array}$ & 1197.12 & 0.82 & $\begin{array}{c}10816.13 \\
(1391.82)\end{array}$ & $\begin{array}{c}13721.42 \\
(767.14)\end{array}$ & 1828.81 & 1.36 \\
\hline Pesticide & $\begin{array}{c}403.10 \\
(141.61)\end{array}$ & $\begin{array}{c}4011.06 \\
(332.12)\end{array}$ & $3412.16^{*}$ & 9.01 & $\begin{array}{c}281.21 \\
(88.01)\end{array}$ & $\begin{array}{c}4642.13 \\
(629.42)\end{array}$ & $4231.12^{* *}$ & 6.7 \\
\hline Other & $\begin{array}{c}10961.96 \\
\text { expenses }\end{array}$ & $\begin{array}{c}11881.24 \\
(889.18)\end{array}$ & 791.21 & 0.68 & $\begin{array}{c}8812.19 \\
(929.13)\end{array}$ & $\begin{array}{c}10567.66 \\
(681.12)\end{array}$ & 1531.12 & 1.41 \\
\hline Total & $\begin{array}{c}(94022.94 \\
(1889.36\end{array}$ & $\begin{array}{c}50261.39 \\
(1532.21)\end{array}$ & $5210.11^{*}$ & 2.03 & $\begin{array}{l}36361.96 \\
(2162.81)\end{array}$ & $\begin{array}{c}50785.92 \\
(2362.29)\end{array}$ & $13011.12^{* *}$ & 3.96 \\
\hline
\end{tabular}

Significant $(\mathrm{p}<0.05) ;{ }^{* *}$ Significant $(\mathrm{p}<0.01)$

Information on table 1 , revealed that the mean expenses for fertilizer on organic farms is PKR 19,897.13 (PKR 100,761.11 and PKR 9,136.46) while the mean expenses for fertilizer on conventional farms is PKR29,978.06 (PKR14,036.60 and PKR 15,941.46). This shows that the amount used to purchase fertilizer used on conventional farms is significantly more than the amount spent on fertilizers for organic farms by $51 \%$ (Table 2). In the aspect of pesticides, a similar situation observed in the cost of fertilizers was the case. It was noted that the type of pesticide applied on the farms were Proton, Safinor, Logran and Bernoxil and was used to control the attack of pests, insects on the farms. The difference here was observed on the quantity applied. Information on Table 3 revealed that pesticide expenses on organic farms is PKR 684.31 (PKR 403.10 and PKR 281.21) and on the conventional farms we had PKR 8,653.19 (PKR 4,011.06 and PKR $4,642.13)$. This clearly shows that the mean expenses on pesticides for organic farms were significantly lower than what is spent on conventional farms. This result clearly revealed that more amount of money is spent on fertilizers and pesticides in conventional farms than in organic farming system, this evidenced that cost of fertilizers and pesticides in conventional farms are usually significantly higher than in organic farms.

In terms of labour force, it was realized that the amount spent on the organic farms was PKR 24,779.54 (PKR13,963.41 and PKR10,816.13) while PKR 26,402.67 (PKR 12,681.25 and PKR 13,721.42) which clearly means that the amount of money spent for labour on conventional farms was significantly higher by $7 \%$ (Table 3). This is in line with the findings of (Clark, 2009; Yasin et al., 2014) who stated that organic farming system have low expenses on labour cost when compared to conventional farming system based on the processes involved in both farming systems. They also emphasized that in comparing the two farming systems, the difference in cost of irrigation and labour can be negligible but the area where much significant difference is observed is in the cost of fertilizers and pesticides.

In terms of other expenses, it was realized that the two farming systems used similar preparation and harvesting methods for their products. This makes the difference in the mean expenses on sundry issues for both farming systems very negligible.

Information on Table 4 shows the mean differences in the amount of yield of wheat from the farms in both study locations. It was also revealed that organic farm outputs or yield was significantly lower than the quantity of yield recorded in the conventional farms. Organic farms were observed to have a mean total yield of $6,889.01 \mathrm{~kg}$ while the conventional farms recorded $8,200.94 \mathrm{~kg}$.

Table-4: Yield (Kg) of wheat per hectare for organic and conventional farms (2019)

\begin{tabular}{|l|c|c|c|c|}
\hline \multicolumn{1}{|c|}{ Yield/hectares } & $\begin{array}{c}\text { Toba Tek } \\
\text { Singh }\end{array}$ & Jhang & $\begin{array}{c}\text { Mean } \\
\text { difference }\end{array}$ & T-statistics \\
\hline Organic & $\begin{array}{c}3628.49 \\
(59.92)\end{array}$ & $\begin{array}{c}3260.52 \\
(125.06)\end{array}$ & $566.03^{* *}$ & 4.63 \\
\hline Conventional & $\begin{array}{c}4482.16 \\
(87.88)\end{array}$ & $\begin{array}{c}3718.78 \\
(124.62)\end{array}$ & $613.66^{* *}$ & 4.02 \\
\hline
\end{tabular}

$*=(\mathrm{p}<0.05) ; * *=(\mathrm{p}<0.01)$ 
This result shows that the yield from conventional farms had a percentage difference of $11 \%$ over the organic farms within the study locations. This result supports the findings of (McBride and Greene, 2009) who posit that conventional farming system have been observed to have more yield than the organic farming system.

Information on Table 5 shows the opinion and assessment of farmers within the study locations on their adopted farming system. The table revealed that $71 \%$ of the farmers who adopted organic farming system expressed confidence on their adopted farming system and $86 \%$ of the conventional farmers expressed confident on their adopted farming system. Meanwhile, $78 \%$ of the organic system farmers hinted that they are ready to change from the adopted farming practice in the coming farming session while $88 \%$ of the conventional farmers also shared the same view. In terms of assessing involvement in multiple occupations among the farmers, it was gathered that more farmers engaged in organic farming system were fully involved in farming as their main and only economic activities $63 \%$ against that of conventional farmers who were only $41 \%$. It was also clearly revealed that more conventional farmers were satisfied with the level of yield from their farms and tracing the success to their adopted farming system with $86 \%$ of agreement while those involved in organic farming had $69 \%$ satisfactory level. This information is in line with the findings of (Khan et al., 2015) who stated that farming activities is a part-time activity which sees most of the people involved in having other businesses to complement the proceeds from the farm. They also emphasized that $31 \%$ of the organic system farmers hinted that they will change their adopted farming system by next session while $14 \%$ of the conventional farmers insisted they will change their adopted farming system by next farming session and it was also revealed that $40 \%$ of the farmers who cultivated conventional crops preferred to consume organic farming products than their conventional crops as they emphasized that the quality of the organic crops were significantly better than the conventional crop based on the fact that organic farmers used natural manure to fertilize their crops while the fertilizers used by the conventional farmers were more of chemicals.

The study focused on comparing the adoption and utilization of organic and conventional farming system in Pakistan. The study revealed that more small scale farmers adopted the use of organic farming system against the conventional farming system which was adopted mainly by large scale farmers at the rate of 51:49 respectively based on the cost effectiveness of practicing organic farming system without considering the level or volume of yield. This is in line with the findings of De Ponti et al. (2012) who realized that most farmers in the least developed countries were more interested in farming system that was more economical in terms of inputs because of the size of farm which they operated.

\section{Table-5: Assessment of farmers on organic and conventional farming systems in the study area}

\begin{tabular}{|l|c|c|c|}
\hline \multicolumn{1}{|c|}{ Item } & $\begin{array}{l}\text { Organic } \\
\text { farmers } \\
\text { (N=153) }\end{array}$ & $\begin{array}{c}\text { Conventional } \\
\text { farmers } \\
\text { (N=147) }\end{array}$ & $\boldsymbol{\mu}$ \\
\hline $\begin{array}{l}\text { Are you confident with the } \\
\text { farming system you } \\
\text { adopted this farming } \\
\text { session }\end{array}$ & $108(71)$ & $127(86)$ & 45.7 \\
\hline $\begin{array}{l}\text { Will you adopt the same } \\
\text { farming system for next } \\
\text { farming session }\end{array}$ & $120(78)$ & $130(88)$ & 52.1 \\
\hline $\begin{array}{l}\text { Farming is my only } \\
\text { occupation }\end{array}$ & $96(63)$ & $62(41)$ & 19.8 \\
\hline $\begin{array}{l}\text { I am involved in other } \\
\text { occupation apart from } \\
\text { farming }\end{array}$ & $57(37)$ & $85(59)$ & 16.1 \\
\hline $\begin{array}{l}\text { I am satisfied with the level } \\
\text { of yield gotten from my } \\
\text { farm }\end{array}$ & $106(69)$ & $126(86)$ & 44.4 \\
\hline $\begin{array}{l}\text { I am not satisfied with my } \\
\text { adopted farming system }\end{array}$ & $47(31)$ & $21(14)$ & 3.3 \\
\hline $\begin{array}{l}\text { I prefer the quality of crop } \\
\text { derived through my adopted } \\
\text { farming system }\end{array}$ & $153(100)$ & $88(60)$ & \\
\hline
\end{tabular}

*, Percentage; $\mu=$ Mean

\section{Conclusion}

The paper examined the inputs and outputs differentials between organic and conventional farming system on wheat farms in Toba Tek Singh and Jhang district, Punjab, Pakistan. Although farmers in the study locations were observed to adopt the farming systems at random with 153 farmers adopting organic farming system while 147 farmers were conventional farming system. The study observed that in terms of inputs, organic farms expended more on irrigation and labor force than conventional farms by $12 \%$ and $7 \%$ respectively. Meanwhile, in terms of fertilizers and pesticides, the conventional system of farming was significantly higher than the organic farms. Further investigation revealed that $31 \%$ of the organic farms believed they would change their adopted farming 
system by next farming session while $14 \%$ of the conventional farmers hinted that they will change their adopted farming session during the next farming session. In this regard, the conventional farmers had more yield than the organic farmers with $11 \%$ difference of the recorded total amount of yield. Based on the findings, the study recommends that farmers should employ more technological strategies in the farming process to ensure more yield and quality of their farm products.

Disclaimer: None.

Conflict of Interest: None.

Source of Funding: None.

\section{References}

Adhikari RK, 2009. Economics of organic vs inorganic carrot production in Nepal. J. Agric. Environ. 10: 27-33.

Bonazzi G and Iotti M, 2014. Interest coverage ratios (ICRs) and financial sustainability: Application to firms with bovine dairy livestock. Am. J. Agric. Biol. Sci. 9: 482.

Clark SF, 2009.The profitability of transitioning to organic grain crops in Indiana. Am. J. Agric. Econ. 91: 1497-504.

De Ponti T, Rijk B and Van Ittersum MK, 2012. The crop yield gap between organic and conventional agriculture. Agric. Syst. 108: 1-9.

FAOSTAT, 2017. FAO Statistical database collections, FAO, Rome. Available fromhttp://www.fao.org/faostat/en/\#country/165 [Accessed 15 January 2019].

Grogan KA, 2012. Comparison of organic and conventional pest management practices among California citrus growers. J. Sust. Agric. 36: 47897.

Husnain M, Khan M and Mahmood H, 2017. An assessment of public and private benefits of organic farming in Pakistan. J. Anim. Plant Sci. 27(3): 996-1004.

Khan M, Mahmood HZ and Damalas CA, 2015. Pesticide use and risk perceptions among farmers in the cotton belt of Punjab, Pakistan. Crop Protec. 67:184-90.

Lusk JL and McCluskey J, 2018. Understanding the impacts of food consumer choice and food policy outcomes. Appl. Econ. Perspec. Policy. 40: 5-21.

McBride WD and Greene C, 2009. Characteristics, costs and issues for organic dairy farming. Economics Research Report Number 82. US Department of Agriculture, Economic Research Service, USA.

Pleadin J, Staver MM, Markov K, Frece J, Zadravec M, Jaki V, Krupic I and Vahcic N, 2017. Mycotoxins in organic and conventional cereals and cereal products grown and marketed in Croatia. Mycotoxin Res. 33: 219-227.

Qiao H, Zheng F, Jiang H and Dong K, 2019. The greenhouse effect of the agriculture-economic growth-renewable energy nexus: Evidence from G20 countries. Sci. Total Environ. 671: 722-731. doi: 10.1016/j.scitotenv.2019.03.336.

Stagnari F, Onofri A, Codianni P and Pisante M, 2013. Durum wheat varieties in $\mathrm{N}$-deficient environments and organic farming: a comparison of yield, quality and stability performances. Plant Breeding. 132: 266-275.

Taylor MK, Sullivan DK, Ellerbeck EF, Gajewski BJ and Gibbs HD, 2019. Nutrition literacy predicts adherence to healthy/unhealthy diet patterns in adults with a nutrition-related chronic condition. Public Health Nutr. 22(12): 2157-2169. doi: 10.1017/S1368980019001289.

Testa R, Di Trapani AM, Foderà M, Sgroi F and Tudisca S, 2014. Economic evaluation of introduction of poplar as biomass crop in Italy. Renew. Sust. Ener. Rev. 38: 775-80.

Yasin MA, Ashfaq M, Adil SA and Bakhsh K, 2014. Profit efficiency of organic vs conventional wheat production in rice-wheat zone of Punjab, Pakistan. J. Agric. Res. 52(3): 439-45

\section{Contribution of Authors}

Aslam W: Data collection, formal analysis, investigation, methodology, visualization and writing an original draft.

Noor RS: Conceptualization of research study, design \& development of the experiment, data collection, formal analysis, investigation, methodology, visualization, writing an original draft and write-up editing.

Ullah S: Performed formal analysis of this manuscript.

Chen H: Investigated, reviewed and supervised the whole research experimental study and the manuscript writing. 